\title{
OPEN Mycoremediation and toxicity assessment of textile effluent pertaining to its possible correlation with COD
}

\author{
Geetanjali Rajhans ${ }^{1}$, Adyasa Barik ${ }^{1}$, Sudip Kumar Sen ${ }^{2}$, Amrita Masanta ${ }^{1}$, \\ Naresh Kumar Sahoo ${ }^{3}$ \& Sangeeta Raut ${ }^{1 \bowtie}$
}

Globally, textile industries are one of the major sectors releasing dye pollutants. This is the first report on the positive correlation between toxicity and chemical oxygen demand (COD) of textile effluent along with the proposed pathway for enzymatic degradation of acid orange 10 using Geotrichum candidum within a very short stretch of time $(18 \mathrm{~h})$. Removal efficiency of this mycoremedial approach after $18 \mathrm{~h}$ in terms of chemical oxygen demand, biological oxygen demand, total suspended solids, salinity, color and dye concentration in the treated effluent reached to $98.5 \%, 56.3 \%, 73.2 \%, 64 \%$, $89 \%$ and $87 \%$ respectively. Also there was a decrease in $\mathrm{pH}$ of the treated effluent. FTIR analysis of the treated effluent confirmed biodegradation. The LCMS analysis showed the degradation of acid orange 10, which was confirmed by the formation of two biodegradation products, 7-oxo-8iminonapthalene-1,3-disulfonate and nitrosobenzene, which subsequently undergoes stepwise hydrogenation and dehydration to form aniline via phenyl hydroxyl amine as intermediate. The X-ray diffraction studies showed that heavy metal content in the treated effluent has reduced along with decrease in \% crystallinity, indicating biodegradation. The connection between toxicity and COD was also inveterated using Pearson's correlation coefficient. Further the toxicological studies indicated the toxicity of raw textile effluent and relatively lower toxic nature of metabolites generated after biodegradation by $G$. candidum.

Urbanization and industrialization have paved the path for development of the many industries, including the textile industries. Clothing and textiles, after agriculture, is the basic requirement of human being. While the textile industry contributes worldwide economically, the environmental effects are due to high volumes of water use and the diversity and quantities of chemicals that are used in all manufacturing phases of textiles. The untreated effluent when disposed in the water bodies seriously impacted the people in the area ${ }^{1}$. Rivers and drainage bodies get loaded with precarious textile effluents that impact on the water quality, aquatic organisms and human life $\mathrm{e}^{2-7}$. The diverse sort of dyes and chemicals used in textile manufacturing makes textile effluents very complex in terms of chemical compositions. According to previous records, in addition to dyes and its auxiliaries over 8000 chemicals are added such as several acids, salts, surfactants, metals, oxidizing and reducing agents ${ }^{8}$. These recalcitrants in untreated effluents are both harmful to marine and terrestrial organisms and have prolonged effects on health ${ }^{9}$.

To assess the performance of wastewater treatment facilities, the influent and treated water samples after each treatment phase (physical, chemical and biological) should be tracked. In general, microbial degradation or bioremediation is known to be a safe, natural, inexpensive and effective pollutant removal technique in the world ${ }^{7,10-12}$. Bioremediation is an innovative clean-up technology that involves the use of bacteria, fungi, actinomycetes, and earthworms ${ }^{13}$. Because of its low cost, high efficiency, and eco-friendly nature, it is a sustainable process for the treatment of organics-rich solid wastes and wastewater produced from various sources ${ }^{14}$. Bioremediation appears to be a promising alternative to other widely used clean-up technologies, such as photocatalytic degradation, because studies have shown that the intermediates released during the photocatalytic degradation process are

${ }^{1}$ Center for Biotechnology, School of Pharmaceutical Sciences, Siksha 'O' Anusandhan (Deemed to be University), Bhubaneswar, Odisha 751003, India. ²Biostadt India Limited, Waluj, Aurangabad, Maharashtra 431136, India. ${ }^{3}$ Department of Chemistry, ITER, Siksha ' $O$ ' Anusandhan (Deemed to be University), Bhubaneswar, Odisha 751003, India. ${ }^{\boxplus}$ email: research.sangeeta@gmail.com 
detrimental to a variety of organisms in the environment ${ }^{15-18}$. Moreover, these processes are also associated with high-energy consumption and capital cost.

However, bacteria typically contribute to the breakdown of textile dyes creating and accumulating more intractable or hazardous aromatic amine substances that restrict their comprehensive applications to azo dye wastewater treatment plants ${ }^{19}$. Enhanced techniques are evidently the pre-condition for accelerated elimination of azo dyes, because any residual contaminants should be removed completely. Fungi have been investigated, especially those secreting non-specific oxidases which eventually lead to the azo dyes mineralization into $\mathrm{CO}_{2}{ }^{20}$. Fungal degradation (Mycoremediation) also leads to complete discoloration and detoxification, which prevents sludge removal and secondary contamination issues.

Geotrichum sp. is one of the few fungi found to degrade large amounts of artificial colors and molasses ${ }^{21-26}$. Because Geotrichum sp has received little attention, it is being used in the current study for the biodegradation and detoxification of textile effluent. In order to confirm the degradation efficiency of the fungus, toxicity evaluation is a requisite. The studies based on toxicity assessments could be done with bioassays using all forms of harmful compounds found in textile effluent and may well be utilized to evaluate the effect of unidentified compounds which cause detrimental, additive and synergistic effects ${ }^{27,28}$.

In the current study, an attempt to validate the non-toxicity of mycoremediated textile effluent as well as its biodegradation analysis such as FTIR, LCMS and XRD have been carried out. Furthermore, bioassays such as genotoxicity, phytotoxicity and microbial toxicity assays have also been conducted so that the toxicity level of raw and treated textile effluent could be assessed.

\section{Materials and methods}

Collection of samples. Samples of textile dyeing effluent have been obtained from a nearby textile factory in Khurda, India. During regular operations, factory workers sampled $100 \mathrm{~mL}$ of wastewater every two hours to ensure that the study involves variability in substances.

Microbial culture conditions. This work utilizes Geotrichum candidum, a ubiquitous fungus belonging to Dipodoascaceae family. It was grown at $35^{\circ} \mathrm{C}$ on Potato Dextrose Agar plates (PDA) (pH-5.6 \pm 0.2 ). Pure fungal culture was inoculated in $3 \%$ malt extract broth after $24 \mathrm{~h}$ to maintain the strain and cultured at $35^{\circ} \mathrm{C}, 100 \mathrm{rpm}$. Using DP media (dextrose and peptone in ratio of $2: 3$ ) at $35^{\circ} \mathrm{C}$ and $100 \mathrm{rpm}$, the optimum fungal growth was achieved $^{25}$.

Analysis of conventional indicators of textile effluent. In this part of the analysis, the G. candidum culture was used to biodegrade the textile effluent. A conical flask containing raw textile effluent (25 ml) was inoculated with fungal culture $(5 \%, \mathrm{v} / \mathrm{v})$, followed by incubation at $35^{\circ} \mathrm{C}, 100 \mathrm{rpm}^{25}$. At regular intervals, aliquots were obtained from the flask and then centrifuged $(10,000 \times \mathrm{g})$ for $10 \mathrm{~min}$. Thereafter, the conventional indicators for raw and treated effluent such as Chemical Oxygen Demand (COD), Biological Oxygen Demand (BOD), Total Suspended Solids (TSS), pH, salinity, color and concentration were assessed following the Standard Methods ${ }^{29}$. COD concentrations were measured using the potassium dichromate method; Pt-Co color scale was used to measure color. TSS estimation was carried out by simple laboratory method ${ }^{30}$. The $\mathrm{pH}$ of water was determined by using a glass electrode $\mathrm{pH}$ meter (Systronics India, Model 362) and salinity was measured by Hanna Salinity Tester (HI98319). Dye concentration of the sample was determined using colorimeter (Systonic, S-912). Every experiment has been carried out in triplicates and standard deviation has been presented with the average data.

The following equation (Eq. (1)) was used to quantify degradation as a percentage reduction of COD:

$$
\% \mathrm{COD}_{\text {reduction }}=\frac{\mathrm{COD}_{\text {initial }}-\mathrm{COD}_{\mathrm{t}}}{\mathrm{COD}_{\text {initial }}} \times 100
$$

$\mathrm{COD}_{\text {initial }}$ : initial value of COD. $\mathrm{COD}_{\mathrm{t}}$ : value of COD at time ' $\mathrm{t}$ ' $(\mathrm{h})$.

Growth kinetics. The following Eq. (2) has been used to determine the specific growth rate of G. candidum.

$$
\ln \frac{x}{x_{0}}=\mu t
$$

$\mathrm{x}$ : biomass concentration $\left(\mathrm{g} \mathrm{L}^{-1}\right)$ at ' $\mathrm{t}$ ' time. $\mathrm{x}_{\mathrm{o}}$ : initial biomass concentration $\left(\mathrm{g} \mathrm{L}^{-1}\right)$ at ' $\mathrm{t}_{0}$ ' time. $\mu$ : specific growth rate $\left(\mathrm{h}^{-1}\right)$.

The expression for growth yield $(\mathrm{Y})$ is

$$
\frac{d x}{d s}=Y
$$

The Eq. 3 can be rewritten as follows ${ }^{31}$ :

$$
x-x_{o}=Y\left(S_{o}-S\right)
$$

$\mathrm{S}_{\mathrm{o}}$ : initial substrate $(\mathrm{COD})$ concentration $\left(\mathrm{mg} \mathrm{L}^{-1}\right)$. S: final substrate $(\mathrm{COD})$ concentration $\left(\mathrm{mg} \mathrm{L}^{-1}\right)$. $\mathrm{x}$ : biomass concentration $\left(\mathrm{mg} \mathrm{L}^{-1}\right) \cdot \mathrm{x}_{\mathrm{o}}$ : initial biomass concentration $\left(\mathrm{mg} \mathrm{L}^{-1}\right)$. 
Analytical studies. The metabolites formed in textile effluent after decolorization and degradation were obtained by same volume with ethyl acetate. The extract was dried over anhydrous sodium sulfate and evaporated to dryness in a rotary evaporator. The resulting crystals were dissolved in small volumes of methanol (HPLC grade), and then used for analysis such as FTIR (Fourier-transform infrared spectroscopy), LCMS (Liquid chromatography-mass spectrometry) and XRD (X-ray Diffraction).

The FTIR analysis of the effluent was performed with Attenuated total reflectance- Fourier transform infrared spectroscopy (ATR-FTIR, FT/IR-4600, JASCO, Japan). A drop from each sample was placed on a Zinc selenide $(\mathrm{ZnSe})$ frame, and the spectra were documented with an average of $32 \mathrm{scans}$ between the 4000 and $600 \mathrm{~cm}^{-1}$ spectral ranges.

The raw and treated samples were also analyzed using LCMS (Waters Micromass Q-Tof Micro) and the flow rate and temperature were maintained at $0.2 \mathrm{ml} \mathrm{min}^{-1}$ and $35^{\circ} \mathrm{C}$, respectively. The running time was $41 \mathrm{~min}$. Two different solvents with varying proportions, such as water with $0.1 \%$ formic acid and acetonitrile with $0.1 \%$ formic acid were used. The deuterium lamp (DL) temperature was set at $250{ }^{\circ} \mathrm{C}$ with $\mathrm{m} / \mathrm{z}$ value $50-1000$ runs in the positive ion mode.

$\mathrm{X}$-ray diffraction patterns before and after biodegradation of textile effluent were recorded using RIGAKUULTIMA IV, Japan diffractometer with monochromatic CuKa radiation $(\lambda=1.5406)$ over the range of $10-90^{\circ}$ $(2 \theta)$. The metals were identified with powder diffraction standard file (JCPDS, Joint Committee on Powder Diffraction Standards Newtown Square, Pennsylvania, USA).

Toxicity study. Phytotoxicity. The phytotoxicity analysis was performed using Phaseolus mungo (at room temperature) on both raw and treated effluent. Simultaneously, the control set was conducted using tap water. After 7 days, toxicity of the raw and treated effluent was evaluated by the length of radical, plumule and germination percentage. Mean with standard deviation for all results were presented.

Microbial toxicity. A short-term toxicity test of textile effluent before and after treatment was demonstrated by exposing the bacteria Escherichia coli (ATCC 443) to the textile effluent for 15 min. Toxicity to E. coli was determined spectrophotometrically by evaluating the difference in the number of cells before and after treatment. All the tests were conducted in triplicate. An experiment with a control set was also carried out.

Genotoxicity Study. The study of genotoxicity was carried out with Allium cepa. Both raw and treated textile effluent was used to treat the roots. The growths after $48 \mathrm{~h}$ of incubation at room temperature were examined ${ }^{32}$. A light microscope (NikonH600L Eclipses LV100) was used to obtain mean values of root length, mitotic index (MI) and chromosomal aberrations in the cell. The experiment was conducted in triplicates and the mean \pm standard deviation values were accounted.

Statistical analysis. The toxicity test results for $E$. coli were expressed as $\mathrm{EC}_{50}$, which represented a $50 \%$ inhibition of $E$. coli growth caused by a percentage concentration of the textile effluent $(\mathrm{v} / \mathrm{v}) . \mathrm{EC}_{50}$ was evaluated via the linear interpolation method $^{33}$.

The Linear Regression method is to fit concentration- inhibition data to a linear regression and then to calculate $\mathrm{EC}_{50}$ values by linear interpolation. The Interpolation log method is according to Huber and Koella ${ }^{34}$ using the following formula, Eq. (5) to calculate the $\mathrm{EC}_{50}$ value.

$$
\log \left(E C_{50}\right)=\log \left(x_{1}\right)+\frac{50 \%-y_{1}}{y_{2}-y_{1}} \times\left[\log \left(x_{2}\right)-\log \left(x_{1}\right)\right]
$$

Direct Interpolation method is similar to interpolation log method but without logarithmic transformation of concentrations. The equation Eq. (6) for $\mathrm{EC}_{50}$ calculation is according to ${ }^{35}$ as follows.

$$
E C_{50}=x_{1}+\frac{50 \%-y_{1}}{y_{2}-y_{1}}\left(x_{2}-x_{1}\right)
$$

$\mathrm{x}_{1}, \mathrm{x}_{2}$ : two conc. of the textile effluent; $\mathrm{y}_{1}, \mathrm{y}_{2}$ : corresponding inhibitions $\left(\mathrm{y}_{1}<50 \% ; \mathrm{y}_{2}>50 \%\right)$. \% Inhibition can be calculated from the following formula $(7)^{36}$

$$
\frac{A_{\text {control }}-A_{\text {sample }}}{A_{\text {control }}} \times 100
$$
37 ,

After evaluation of $\mathrm{EC}_{50}$, the toxicity of all samples were expressed as toxic units, TU (unitless), as per Eq. (8)

$$
T U_{50}=100 / E C_{50}
$$

The Pearson's correlation coefficient at the significance level of 0.05 was used to assess the correlation between toxicity and conventional indicators of the raw and treated textile effluent, and the impact of COD on toxicity was analyzed by means of linear regression. The significance level of the regression analysis $(\mathrm{p})$ and $\mathrm{R}^{2}$ illustrated the extent of toxicity variance caused by COD. 


\begin{tabular}{|l|l|l|l|}
\hline Indicators & Raw textile effluent & Treated textile effluent (after 18 h) & $\begin{array}{l}\text { Removal (\%) } \\
(\mathbf{a f t e r ~ 1 8 ~} \mathbf{h})\end{array}$ \\
\hline $\mathrm{COD}\left(\mathrm{mg} \mathrm{L}^{-1}\right)$ & $902.1 \pm 0.05$ & $13.20 \pm 0.05$ & $\mathbf{9 8 . 5}$ \\
\hline BOD $\left(\mathrm{mg} \mathrm{L}^{-1}\right)$ & $350.3 \pm 0.02$ & $153.08 \pm 0.02$ & $\mathbf{5 6 . 3}$ \\
\hline pH & 7.9 & 7 & - \\
\hline TSS $\left(\mathrm{mg} \mathrm{L}^{-1}\right)$ & $320 \pm 0.05$ & $85.5 \pm 0.05$ & $\mathbf{7 3 . 2}$ \\
\hline Salinity (PSU) & 0.25 & 0.09 & $\mathbf{6 4}$ \\
\hline Color (hazen units) & 35,400 & 3894 & $\mathbf{8 9}$ \\
\hline Concentration of sample(ppm) & 3100 & 400 & $\mathbf{8 7}$ \\
\hline
\end{tabular}

Table 1. Conventional indicators in raw and treated textile effluent. ${ }^{\star}$ PSU- Practical Salinity Units.

\section{Results and discussion}

Conventional indicators of textile effluent. The conventional indicators of raw and treated textile effluent have been listed in Table 1. It was evident that the raw textile effluent was high in COD, BOD, TSS and salinity $^{38}$, which was way much higher than the permitted levels (COD- less than $250 \mathrm{mg} \mathrm{L}^{-1}$, BOD- less than $30 \mathrm{mg} \mathrm{L}^{-1}$, TSS- less than $100 \mathrm{mg} \mathrm{L}^{-1}$ in India). Studies show that common components of dye effluents such as some acid dyes and ionic dyes could easily escape into the environment leading to elevating levels of COD, BOD, TSS, salinity and coloration of water bodies ${ }^{39}$. After treatment, it was observed that G. candidum was able to remove COD (98.5\%), BOD (56.3\%), TSS (73.2\%), salinity (64\%), dye concentration (87\%), color (89\%) from the textile effluent in $18 \mathrm{~h}$, which meets the discharge standards. Also the $\mathrm{pH}$ of the treated effluent was found to drop and reach neutral point. The high removal efficiency of $G$. candidum improved the quality of textile effluent in terms of COD, BOD and color. A recent study showed the reduction in COD, BOD and color of the textile effluent by $77.5 \%, 71.0 \%$ and $99.2 \%$ respectively in $24 \mathrm{~h}$ after treatment with Aspergillus niger ${ }^{40}$. Yet another study showed that $91 \%, 88 \%$ and $68 \%$ reduction was recorded in the color intensity, COD and BOD of the textile wastewater, respectively, after treatment with Peyronellaea prosopidis ${ }^{41}$.

Growth kinetics studies. The specific growth rate of $0.127 \mathrm{~h}^{-1}$ and yield coefficient of $2.64 \mathrm{mg}$ of dry weight of biomass $\mathrm{mg}^{-1}$ COD were obtained for the biodegradation using G. candidum. This indicated that $G$. candidum was able to thrive in the extreme conditions of the effluent, reducing COD efficiently. The literatures reported the specific growth rate of $0.116 \mathrm{~h}^{-1}$ and yield coefficient of $1.22 \mathrm{mg}$ of dry weight of biomass $/ \mathrm{mg}$ $\mathrm{COD}^{31}$. Yet another report showed the specific growth rate varying from 0.001 to $0.003 \mathrm{~h}^{-1}$ and yield coefficient varying from 0.25 to $0.75 \mathrm{mg}$ of dry weight of biomass $\mathrm{mg}^{-1} \mathrm{COD}^{42}$.

Characterization of biodegraded textile effluent. FTIR G. candidum-induced effluent biodegradation which was established through FTIR spectral analyses (Fig. 1). The process of biodegradation is demonstrated either by loss of absorbance peaks or by the occurrence of new peaks ${ }^{43,44}$. The FTIR spectrum of the untreated effluent represented the variable stretching vibrations of $\mathrm{C}=\mathrm{C}$ (alkyne), $\mathrm{P}-\mathrm{H}$ (phosphine) and $\mathrm{N}-\mathrm{H}($ amine) at $2127 \mathrm{~cm}^{-1}, 2360 \mathrm{~cm}^{-1}$ and $3348 \mathrm{~cm}^{-1}$ respectively. The biodegradation products obtained after $18 \mathrm{~h}$ of treatment showed disappearance of phosphine group and occurrence of a new peak at $530 \mathrm{~cm}^{-1}$, representing the occurrence of strong stretching vibration of $\mathrm{C}-\mathrm{Br}$ (alkyl bromide) (Fig. 1). The biodegradation of raw textile effluent by G. candidum was clearly established in this study. Previous studies have established that the biodegradation of textile dyes can be confirmed by FTIR spectrum representing occurrence of new peaks ${ }^{44}$. The signal in IR at $1634 \mathrm{~cm}^{-1}$, which corresponds to aldehyde. Thus aldehyde, one of the intermediate, formed during degradation of acid orange is confirmed. During the degradation there is asymmetric cleavage of azo bond in acid orange resulting in formation of nitrosobenzene, which was confirmed by the standard GC-MS library data, this is further converted to aniline and later on aromatic ring cleavage leading to complete mineralization. While the naphthalene part of the dye was further biodegraded with opening of one ring, the formation of aldehyde as one of the intermediate is confirmed from the IR data. On the basis of above results, it can be concluded that G. candidum has ability to mineralize acid orange completely. Similar results were demonstrated by previous studies ${ }^{45}$.

LCMS In positive ion and full scanning mode, the textile dye effluent was analyzed from 100 to $1000 \mathrm{~m} / \mathrm{z}$. Several mass peaks of varying values have been observed with both raw and treated effluent (Fig. 2a). For the raw effluent, a mass peak at $453 \mathrm{~m} / \mathrm{z}$ (m.w. 452) was identical to that of an azo dye, acid orange 10 (Fig. 2b). Hence, it was evident that the acid orange 10 was a major dye component of the textile effluent used in this study. The identification of metabolites produced prior to biodegradation of effluent was carried out and the plausible biodegradation pathway based on the previous reports was predicted ${ }^{46}$. The secretion and involvement of ligninolytic enzymes (laccase and lignin peroxidase) in the azo dye degradation process of G. candidum was evident from our previous study ${ }^{25}$. The degradation of acid orange 10 by peroxidase leads to the formation of two biodegradation products such as 7-oxo-8-iminonapthalene -1,3-disulfonate and nitrosobenzene, which subsequently undergoes stepwise hydrogenation and dehydration to form aniline (m.w. 93, m/z 91) (Fig. 2c), via phenyl hydroxyl amine intermediate (as proposed by Mahata and co-workers ${ }^{47}$. The degradation pathway has been predicted in Fig. 3. Aniline was found in the treated effluent as a low molecular weight compound, rendering it less toxic.

$X R D$ Heavy metal ions can be prevalent in textile effluent because of the metal-associated dyes and/or additional components used in the dyeing process. The X-ray spectra obtained for the dried samples of the untreated and treated effluent after $18 \mathrm{~h}$ treatment with G. candidum are shown in Fig. 4. This displayed various peaks 


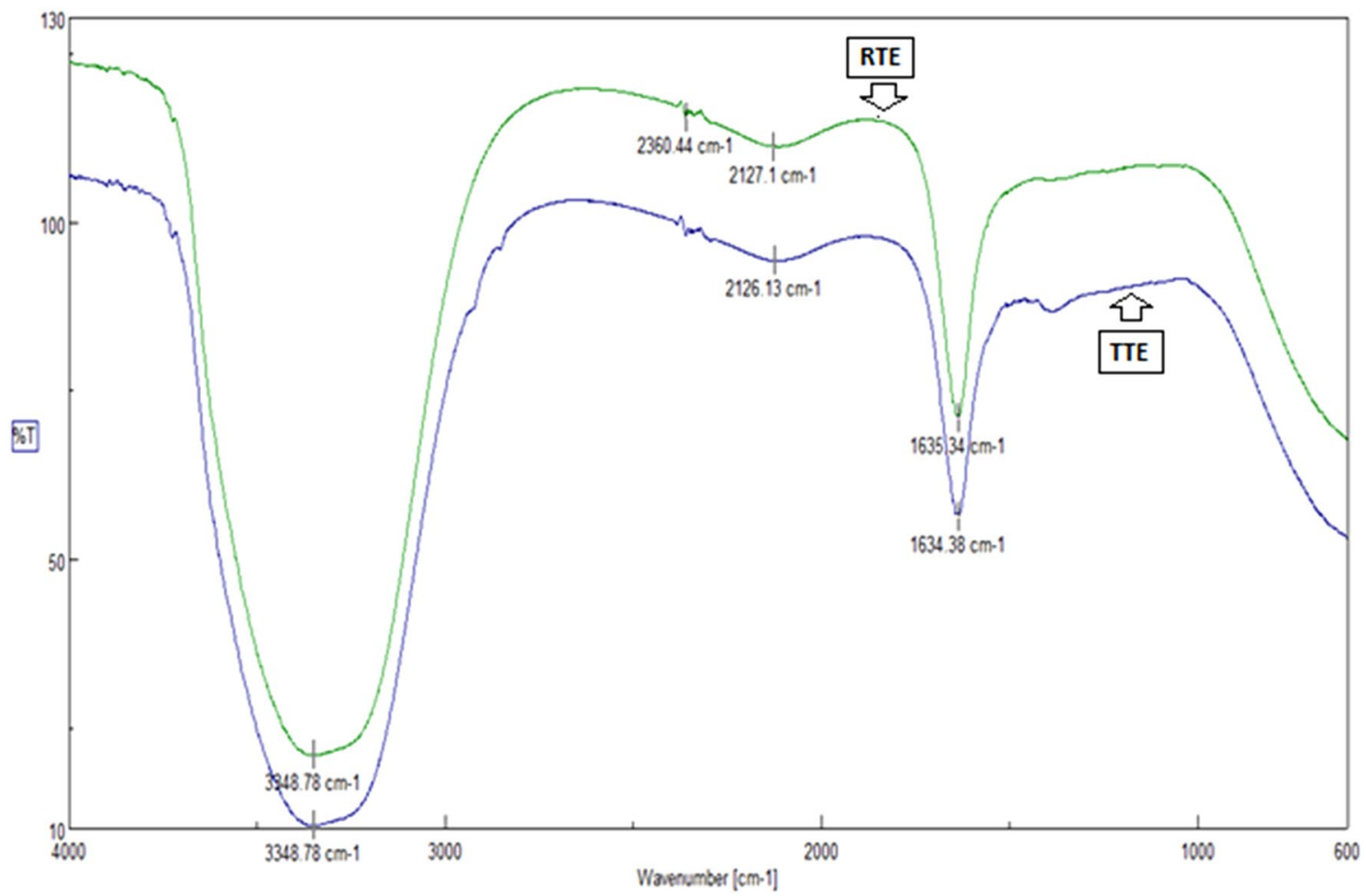

Figure 1. FT-IR spectral analyses of raw and treated textile effluent.
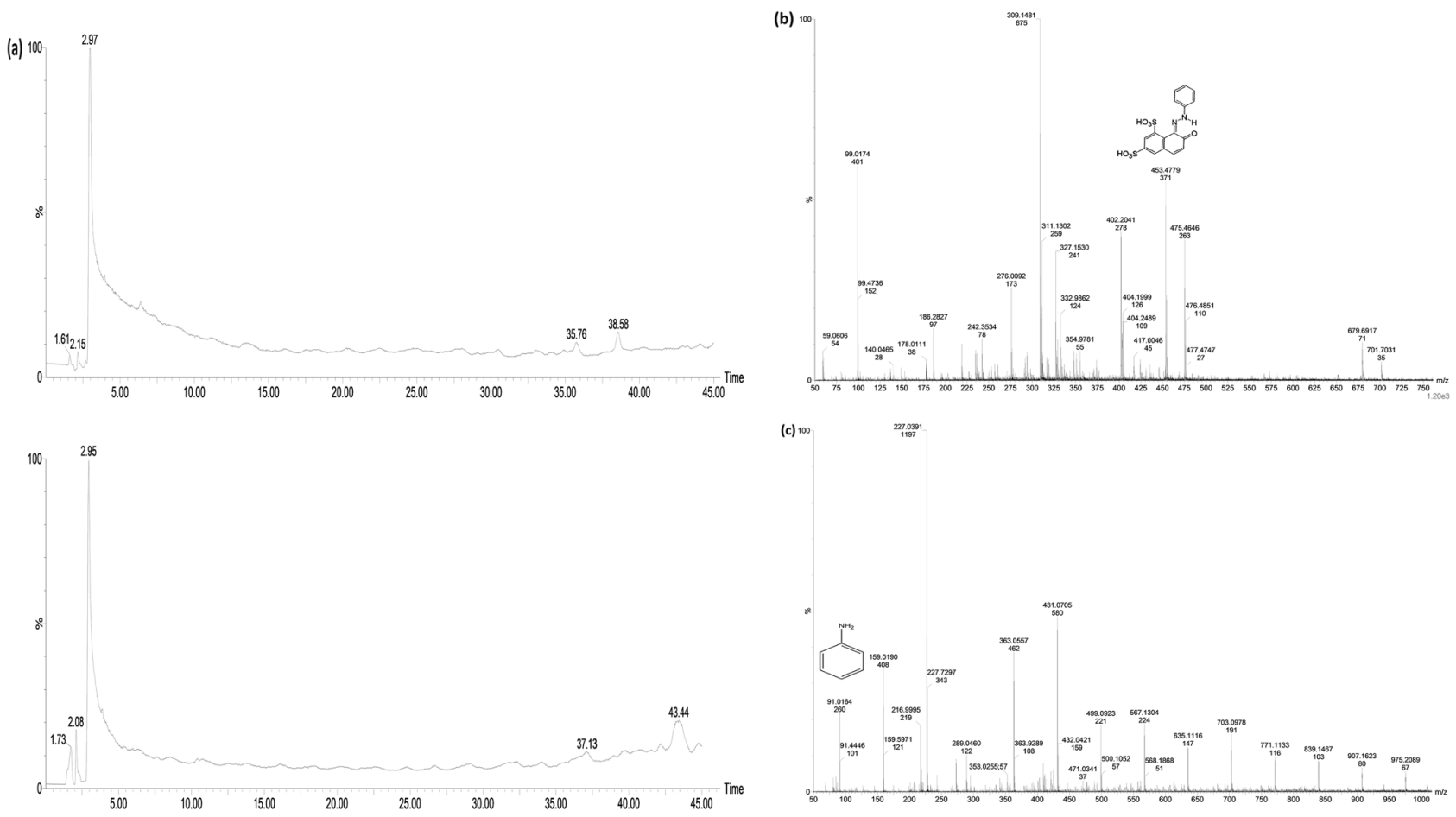

Figure 2. LCMS analysis of raw and treated textile effluent.

that specifically indicated the presence of metals in raw effluent. The $2 \theta$ values of $32.36^{\circ}$ and $50.5^{\circ}$ show the presence of major metals, such as lead and mercury respectively. The presence of these metals was confirmed using standard JCPDS reference codes $(04-0686(\mathrm{~Pb})$ and $01-085-0211(\mathrm{Hg}))$. Subsequently, the X-ray spectra of treated effluent showed the absence of $\mathrm{Pb}$ as well as the considerable decrease in the peak intensity for $\mathrm{Hg}$ indicating the decreased toxicity of the effluent (Fig. 4). A decrease in \% crystallinity was observed in the textile 

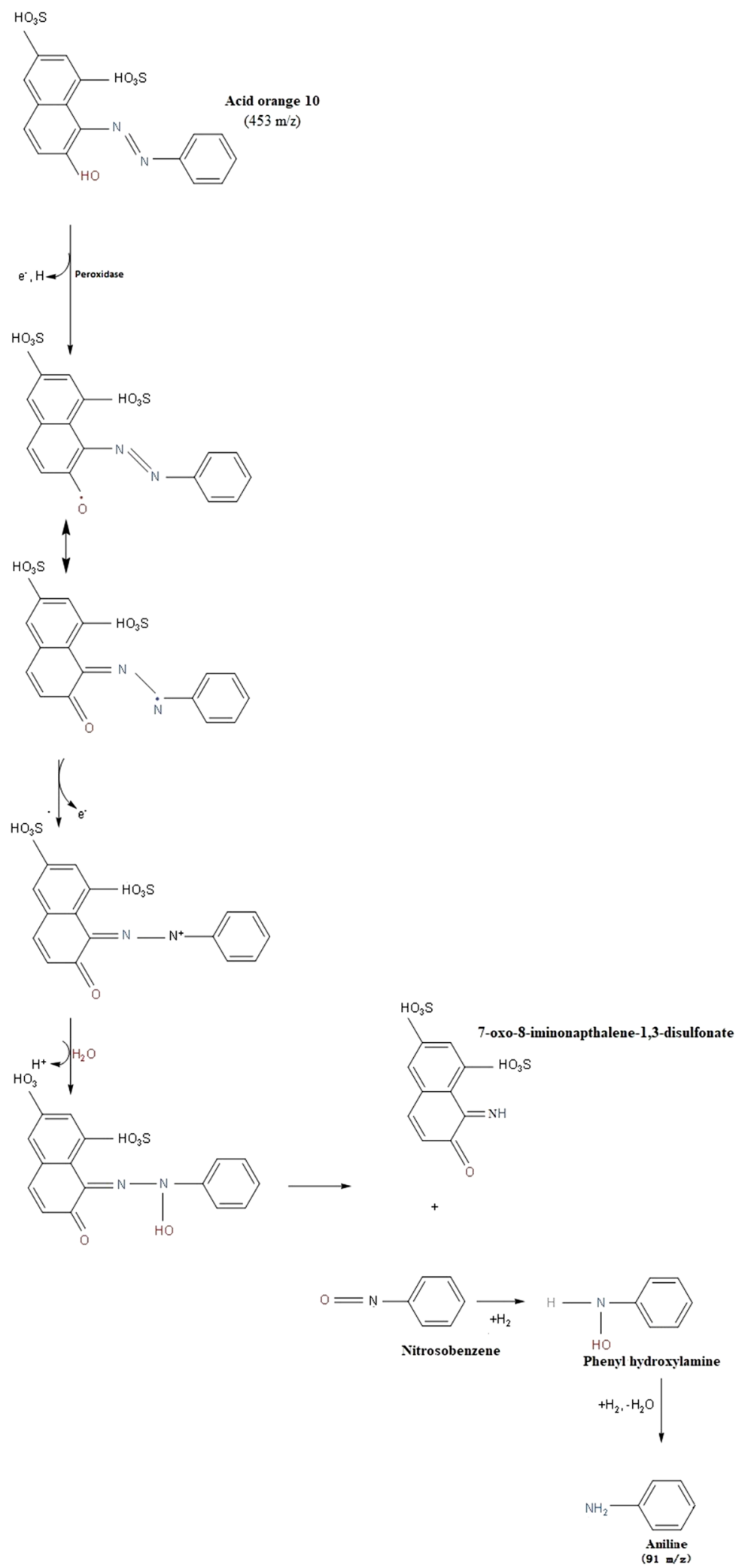

Figure 3. Proposed pathway for degradation of acid orange 10 dye by G. candidum (Images have been drawn using the software KingDraw (v1.1.0, http://www.kingdraw.cn/en/download.html). 


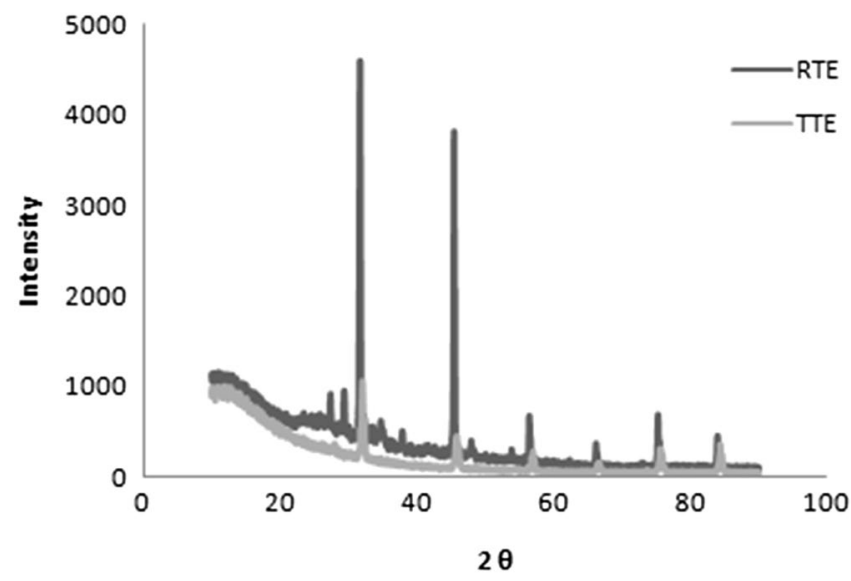

Figure 4. X-ray diffraction pattern of raw and treated textile effluent.

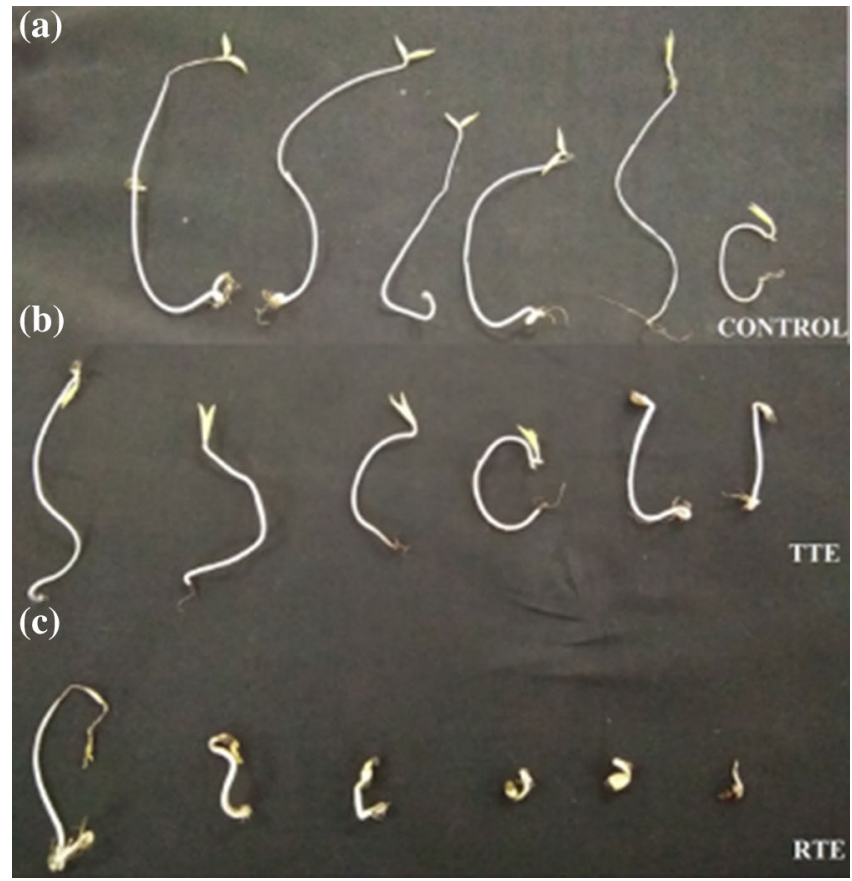

Figure 5. Phytotoxicity analysis of (a) Control (Tap water), (b) Treated textile effluent, (c) Raw textile effluent on P. mungo.

effluent after it was exposed to G. candidum, indicating the degradation of the effluent. Previous studies have demonstrated similar removal of heavy metals from textile effluent ${ }^{31}$. The presence of heavy metals in the effluent leads to numerous health hazards and sequential treatment would eliminate the heavy metals, and make the treated effluent more safe to discharge into the environment.

Toxicity evaluation. Phytotoxicity. Agriculturally valuable seeds i.e. P. mungo were used for phytotoxicity assessment of raw and treated textile effluent. The analyzed parameters were germination percentage, plumule and radical length. In control set, i.e., seeds germinated in tap water, $100 \%$ germination was observed after 7 days, which reduced to about $33 \%$ in case of raw textile effluent $(P>0.05)$ (Fig. 5). Though some of the seeds exposed to raw textile effluent germinated, they couldn't grow further, exhibiting maximum phytotoxicity. Similar studies on the toxic effects of azo dye-laden textile effluent on the seed germination has been reported ${ }^{48,49}$. The study on inhibitive effect of azo dyes on plants by Zhou and Xiang showed that the azo dyes inhibit the ATPase activity of plants, photosynthetic oxygen evolution and plant growth. In the current study, due to the higher degradation of textile effluent by G. candidum, a germination rate of $100 \%$ was recorded in $P$. mungo with treated textile effluent. It was indicative that the metabolites formed after effluent biodegradation are less harmful than the compound present in the raw textile effluent. The results shown in Table 2 indicated that the germination (\%) 


\begin{tabular}{|l|l|l|c|}
\hline Parameters & Control & Raw textile effluent & Treated textile effluent \\
\hline Germination $(\%)$ & $98 \pm 0.08$ & $33 \pm 0.06$ & $95 \pm 0.03$ \\
\hline Plumule $(\mathrm{cm})$ Mean \pm SD & $6.86 \pm 0.954$ & $0.28 \pm 0.577$ & $0.6 \pm 0.441$ \\
\hline Radicle $(\mathrm{cm})$ Mean \pm SD & $8.38 \pm 2.399$ & $3.15 \pm 1.755$ & $6.46 \pm 1.503$ \\
\hline
\end{tabular}

Table 2. Phytotoxicity study of untreated and treated textile effluent on $P$. mungo. Values are mean of three experiments, $\mathrm{SD}( \pm)$, significantly different from the control (seeds germinated in water) at $P>0.05$ (One-way analysis of variance, ANOVA).

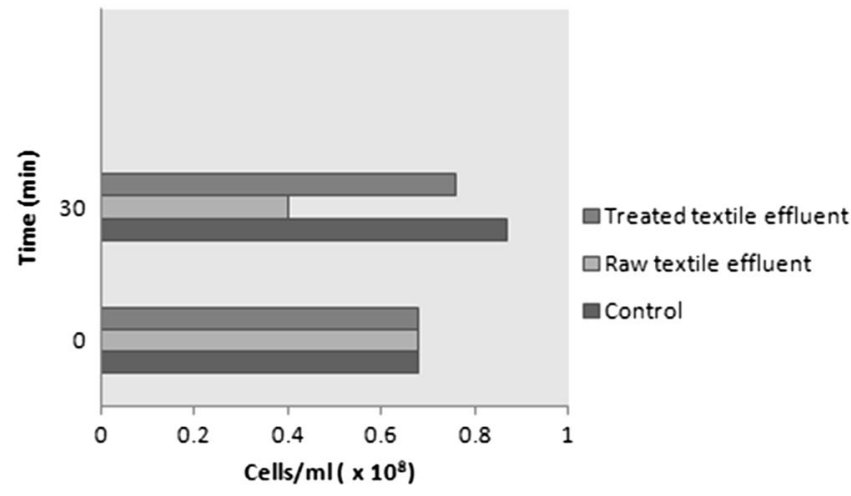

Figure 6. Microbial toxicity analysis of (a) Control (culture medium), (b) Treated textile effluent, (c) Raw textile effluent on E. coli.

and length of plumule and radicle of $P$. mungo seeds were less with the untreated as compared to treated effluent. This study showed that the seed germination and average plumule and radical development were unaffected by decolored textile effluent. A significant decrease $(P>0.05)$ in the average plumule and radical of the germinated seeds was found in the untreated textile effluent. Thus, the comprehensive results indicated that the textile effluent treated with G. candidum was not harmful to plant germination and growth. This ensures that treated effluent could be used for agriculture or recycled.

Toxicity test with E. coli. The short-term toxicity of the raw and treated textile effluent was assessed using the well-established bacteria E. coli and the results are shown in Fig. 6. The raw textile effluent was highly toxic, while treated textile effluent presented a low toxicity. Figure 6 shows that after $30 \mathrm{~min}$ of exposure to raw textile effluent, the number of bacterial cells declined drastically by approximately $41 \%$, indicating acute toxicity to $E$ coli. This was plausibly due to the enormous amount of ionic and acid dyes entering the wastewater during the textile processing. Ionic and disperse dyes discharged from textile processing and dyeing were usually particularly toxic, and some were mutagenic and carcinogenic ${ }^{50,51}$. On the contrary, it was found that the treated effluent was absolutely harmless to the bacteria, which was evident from their uninhibited growth (cells/ml increased by approximately 10\%). This indicates that the toxicity of textile effluent was reduced to a greater extent after treatment with G. candidum.

Genotoxicity analysis. The A. cepa study is a standard test to assess the genotoxicity of any toxic substance. The test was carried out to identify MI and chromosomal aberrations in the root cells (Table 3). On the basis of the MI value, (MI value can act as a biosensor for environmental contaminants) the cytotoxic effect of the toxic compound was assessed ${ }^{52}$. Table 3 shows the genotoxic aspects of the textile effluent before and after treatment. The decreased MI value is indicative of decreased cytotoxicity of treated effluent. The textile wastewater typically has a detrimental impact on chromosomal cell division, and this type of aberrations in mitotic cell division is triggered by spindle apparatus proteins malfunctioning ${ }^{32,53,54}$ or probably due to decrease in ATP synthesis during cell division. The significant reduction in COD level could then contribute to the decline in the number of aberrant mitotic cells after treatment. The findings recorded were similar to the literature data ${ }^{52,54}$.

The decrease in colour, COD and BOD might have led to the minimization in the toxicity of textile effluent. This study indicates that the metabolites produced after biodegradation are less toxic than the compounds present in raw effluent.

Relationship between toxicity and COD of raw and treated textile effluent. Pearson's correlation analysis for the textile effluent indicated a significantly positive correlation between COD and $\mathrm{TU}_{50}(\mathrm{r}=0.920, P<0.05$, $\mathrm{R}^{2}=0.84$ ), which suggested that compounds present in the textile effluent were toxic to $E$. coli. However, there was a negative relationship between $\mathrm{COD}$ and $\mathrm{TU}_{50}\left(\mathrm{r}=0.088, P=0.048, \mathrm{R}^{2}=0.77\right)$ in case of treated textile efflu- 


\begin{tabular}{|l|l|l|}
\hline Analysis & Raw Effluent & Treated effluent \\
\hline RL $(\mathrm{cm})$ & $3.28 \pm 0.65$ & $5.84 \pm 0.41$ \\
\hline MI & $0.3 \pm 1.32$ & $0.9 \pm 0.562$ \\
\hline MN & Not found & Not found \\
\hline CB & 3 & 1 \\
\hline TA & 3 & 1 \\
\hline TCA & 50 & 50 \\
\hline Frequency of TA & $0.5 \pm 0.04^{*}$ & $0.25 \pm 0.005$ \\
\hline
\end{tabular}

Table 3. Genotoxicity analysis for the raw and treated effluent. RL- root length; MI- Mitotic index; MNmicronuclei; CB- Chromosome breaks; TCA- total no. of cells analysed; TA-Total no. of alterations. Values are mean of three experiments, ${ }^{\star} P<0.05,{ }^{\star *} P<0.001$ by one-way analysis of variance (ANOVA) with TukeyKramer comparison test.

ent. Similar toxicity and COD correlation studies for textile effluent have been carried out with Vibrio fischeri and Desmodesmus subspicatus. They showed that there was a significant positive correlation between $V$. fischeri and COD; color and $\mathrm{TU}_{50}(\mathrm{r}=0.824,0.57, P<0.05)$, which suggested that compounds producing color might be toxic for $V$. fischeri. However, there was a negative relationship between $D$. subspicatus and $\mathrm{TU}_{50}(\mathrm{r}=0.625$, $P=0.035)^{55}$.

$\mathrm{COD}$ is one of the most widely used water quality monitoring metrics and also an important measure for the regulation of the usage of wastewater treatment facilities, taxation and surveillance of wastewater effluent ${ }^{56}$. Therefore, it was important to establish associations between bio-toxicity and conventional markers such as COD $^{57}$.

\section{Conclusion}

The competent Geotrichum candidum culture involved in the current work biodegraded the toxic textile effluent. The analysis of conventional parameters such as COD, BOD and color were indicative of the decreased toxicity of the treated effluent in comparison to the raw effluent. The effective decolorization and biodegradation of effluent in $18 \mathrm{~h}$ was confirmed by FTIR and XRD analysis. The plausible biodegradation pathway has been proposed on the basis of metabolites identified by LCMS. This demonstrated the first report on the proposed pathway for enzymatic degradation study of acid orange 10 by G. candidum. The genotoxicity, phytotoxicity and microbial toxicity analyses proved the raw effluent is harmful, whereas the treated effluent is less toxic. Relationship between effluent $\mathrm{COD}$ and $\mathrm{TU}_{50}$ showed that an increase in effluent COD resulted in increase in wastewater toxicity. There was a clearly defined correlation between toxicity and COD. It was evident that toxic effects of the textile effluent were significantly reduced upon treatment with G. candidum. The major relationships between toxicity and COD will provide directions for more efficient control of textile dyeing effluents. This is the first report on the positive correlation between toxicity and COD of textile effluent using G. candidum within a very short stretch of time $(18 \mathrm{~h})$. Therefore, the findings of this study have shown that the treated effluent was safer to be released in regard to physicochemical parameters and toxicity unit $\left(\mathrm{TU}_{50}\right)$. The correlation between conventional indicators and toxicity may provide assistance in effluent management.

\section{Ethics approval}

Not applicable.

\section{Consent to participate}

Not applicable.

\section{Consent for publication}

The authors have their consent for the publication of this manuscript if accepted.

\section{Availability of data and materials}

Not applicable.

\section{Code availability}

Not applicable.

Received: 24 March 2021; Accepted: 16 June 2021

Published online: 05 August 2021

\section{References}

1. Agrawal, K. \& Verma, P. Biodegradation of synthetic dye Alizarin Cyanine Green by yellow laccase producing strain Stropharia sp. ITCC-8422. Biocatal. Agric. Biotechnol. 21, 101291 (2019).

2. Kumar, V., Upadhyay, N., Singh, S., Singh, J. \& Kaur, P. Thin-layer chromatography: Comparative estimation of Soil's atrazine. Curr. World Environ. J. 8, 469-472 (2013).

3. Kumar, V. et al. Bioremediation of Petroleum hydrocarbon by using Pseudomonas species isolated from Petroleum contaminated soil. Orient. J. Chem. 30, 1771-1776 (2014). 
4. Kumar, V. et al. Bioremediation of heavy metals by employing resistant microbial isolates from agricultural soil irrigated with Industrial Waste water. Orient. J. Chem. 31, 357-361 (2015).

5. Kumar, V., Singh, S., Singh, J. \& Upadhyay, N. Potential of plant growth promoting traits by bacteria isolated from heavy metal contaminated soils. Bull. Environ. Contam. Toxicol. 94, 807-814 (2015).

6. Singh, N. \& Balomajumder, C. Simultaneous biosorption and bioaccumulation of phenol and cyanide using coconut shell activated carbon immobilized Pseudomonas putida (MTCC 1194). J. Environ. Chem. Eng. 4, 1604-1614 (2016).

7. Mishra, V. et al. Synergistic effects of Arbuscular mycorrhizal fungi and plant growth promoting rhizobacteria in bioremediation of iron contaminated soils. Int. J. Phytoremediation 18, 697-703 (2016).

8. Reddy, S. \& Osborne, J. W. Biodegradation and biosorption of Reactive Red 120 dye by immobilized Pseudomonas guariconensis: Kinetic and toxicity study. Water Environ. Res. 92, 1230-1241 (2020).

9. Hamidi, R. \& M., Jovanova, B. \& Kadifkova Panovska, T. ,. Toxicological evaluation of the plant products using Brine Shrimp (Artemia salina L.) model. Maced. Pharm. Bull. 60, 9-18 (2014).

10. Kumar, V., Singh, S., Singh, R., Upadhyay, N. \& Singh, J. Design, synthesis, and characterization of 2,2-bis(2,4-dinitrophenyl)-2(phosphonatomethylamino)acetate as a herbicidal and biological active agent. J. Chem. Biol. 10, 179-190 (2017).

11. Singh, S. et al. Toxicity, degradation and analysis of the herbicide atrazine. Environ. Chem. Lett. 16, 211-237 (2018).

12. Singh, S. et al. Efficient biodegradation of acephate by Pseudomonas pseudoalcaligenes PS-5 in the presence and absence of heavy metal ions [Cu(II) and $\mathrm{Fe}(\mathrm{III})]$, and humic acid. 3 Biotech 7, 262 (2017).

13. Mazzeo, D. E. C., Fernandes, T. C. C. \& Marin-Morales, M. A. Cellular damages in the Allium cepa test system, caused by BTEX mixture prior and after biodegradation process. Chemosphere 85, 13-18 (2011).

14. Chang, Y., Lo, T., Chou, H. \& Laio, Y. L. Anaerobic biodegradation of decabromodiphenyl ether (BDE-209)-contaminated sediment by organic compost. Int. Biodeterior. Biodegradation 113, 228-237 (2016).

15. Barnes, R. J., Molina, R., Xu, J., Dobson, P. J. \& Thompson, I. P. Comparison of TiO2 and ZnO nanoparticles for photocatalytic degradation of methylene blue and the correlated inactivation of gram-positive and gram-negative bacteria. J. Nanoparticle Res. 15, $1432(2013)$.

16. Ghosh, M., Chakraborty, A. \& Mukherjee, A. Cytotoxic, genotoxic and the hemolytic effect of titanium dioxide (TiO 2) nanoparticles on human erythrocyte and lymphocyte cells in vitro. J. Appl. Toxicol. 33, 1097-1110 (2013).

17. Goncalves, D. M. \& Girard, D. Zinc oxide nanoparticles delay human neutrophil apoptosis by a de novo protein synthesisdependent and reactive oxygen species-independent mechanism. Toxicol. Vitr. 28, 926-931 (2014).

18. Leung, Y. H. et al. Toxicity of CeO2 nanoparticles: The effect of nanoparticle properties. J. Photochem. Photobiol. B Biol. 145, 48-59 (2015).

19. Davies, L. C., Pedro, I. S., Novais, J. M. \& Martins-Dias, S. Aerobic degradation of acid orange 7 in a vertical-flow constructed wetland. Water Res. 40, 2055-2063 (2006).

20. Wanderley, C. R. P., Andrade, M. V., Pereira, L. J., Silva, G. M. M. \& Pessoa, K. R. Azo dye mineralization by Phanerochaete Chysosporium in a sequencing bath reactor. Braz. Arch. Biol. Technol. 2018, 61 (2018).

21. SeongJun Kim; Makoto Shoda. Decolorization of molasses by a new isolate of Geotrichum candidum in a jar fermenter. Biotechnol. Tech. 12, 497-499 (1998).

22. Kim, S. J. \& Shoda, M. Decolorization of molasses and a dye by a newly isolated strain of the fungusGeotrichum candidum Dec 1. Biotechnol. Bioeng. 62, 114-119 (1999).

23. Shintani, N. \& Shoda, M. Decolorization of oxygen-delignified bleaching effluent and biobleaching of oxygen-delignified kraft pulp by non-white-rot fungus Geotrichum candidum Dec 1. J. Environ. Sci. 25, S164-S168 (2013).

24. Yin, L., Chen, Z.-H. \& Zhao, S.-J. Optimization of laccase production from Geotrichum candidum and decoloration of azo dyes by laccase. Res Square 36, 85-90 (2008).

25. Rajhans, G., Sen, S. K., Barik, A. \& Raut, S. Elucidation of fungal dye-decolourizing peroxidase (DyP) and ligninolytic enzyme activities in decolourization and mineralization of azo dyes. J. Appl. Microbiol. 129, 1633-1643 (2020).

26. Rajhans, G., Kumar Sen, S., Barik, A. \& Raut, S. De-colorization of textile effluent using immobilized Geotrichum candidum : An insight into mycoremediation. Lett. Appl. Microbiol. 72(4), 445-457 (2020).

27. Yu, W. et al. Application of a novel alkali-tolerant thermostable dyp-type peroxidase from Saccharomonospora viridis DSM 43017 in biobleaching of eucalyptus kraft pulp. PLoS ONE 9, 110319 (2014).

28. Ma, K., Qin, Z., Zhao, Z., Zhao, C. \& Liang, S. Toxicity evaluation of wastewater collected at different treatment stages from a pharmaceutical industrial park wastewater treatment plant. Chemosphere 158, 163-170 (2016).

29. E.W. Rice, R.B. Baird, A.D. Eaton, E. APHA Standard Methods For The Examination Of Water And Wastewater, 23rd ed. (American Public Health Association, American Water Works Association, Water Environment Federation, 2017).

30. Tufekci N., San H.A., Aydin S., U. S. and B. H. Wastewater Treatment Problems in the Operation of Woven and Knit Fabric Industry. Fed. Eur. Biochem. Soc. 7, 795-802 (1998).

31. Vijayalakshmidevi, S. R. \& Muthukumar, K. Improved biodegradation of textile dye effluent by coculture. Ecotoxicol. Environ. Saf. 114, 23-30 (2015).

32. Wijeyaratne, W. M. D. N. \& Wadasinghe, L. G. Y. J. G. Allium cepa Bio Assay to Assess the Water and Sediment Cytogenotoxicity in a Tropical Stream Subjected to Multiple Point and Nonpoint Source Pollutants. J. Toxicol. 2019, 1-10 (2019).

33. Teresa J Norberg-King. A linear interpolation method for sublethal toxicity: The inhibition concentration (ICp) approach (version 2.0). (National Effluent Toxicity Assessment Center (NETAC) Technical Report, USEPA, Duluth, MN, 1993). 03-93

34. Huber, W. \& Koella, J. C. A comparison of three methods of estimating EC50 in studies of drug resistance of malaria parasites. Acta Trop. 55, 257-261 (1993).

35. Alexander, B., Browse, D. J., Reading, S. J. \& Benjamin, I. S. A simple and accurate mathematical method for calculation of the EC50. J. Pharmacol. Toxicol. Methods 41, 55-58 (1999).

36. Wang, J. et al. Antimicrobial and antioxidant activities of the root bark essential oil of Periploca Sepium and its main component 2-hydroxy-4-methoxybenzaldehyde. Molecules 15, 5807-5817 (2010).

37. Sprague, J. B. Measurement of pollutant toxicity to fish. II. Utilizing and applying bioassay results. Water Res. 4, 3-32 (1970).

38. Yaseen, D. A. \& Scholz, M. Shallow pond systems planted with Lemna minor treating azo dyes. Ecol. Eng. 94, 295-305 (2016).

39. Islam, M. R. \& Mostafa, M. G. Characterization of textile dyeing effluent and its treatment using polyaluminum chloride. Appl. Water Sci. 10, 119 (2020).

40. Gurbuz, F., Ozcan, A., Ciftci, H., Acet, O. \& Odabasi, M. Treatment of textile effluents through bio-composite column: Decolorization and COD reduction. Int. J. Environ. Sci. Technol. 16, 8653-8662 (2019).

41. Bankole, P. O., Adekunle, A. A., Obidi, O. F., Chandanshive, V. V. \& Govindwar, S. P. Biodegradation and detoxification of Scarlet RR dye by a newly isolated filamentous fungus, Peyronellaea prosopidis. . Sustain. Environ. Res. 28, 214-222 (2018).

42. Bayram, T. T., Nuhoğlu, A. \& Aladağ, E. Investigation of biodegradation and growth kinetics of dairy wastewater in a batch reactor. Bulg. Chem. Commun. 49, 896-900 (2017).

43. Chen, K.-C., Wu, J.-Y., Liou, D.-J. \& Hwang, S.-C.J. Decolorization of the textile dyes by newly isolated bacterial strains. J. Biotechnol. 101, 57-68 (2003).

44. Sen, S. K., Patra, P., Das, C. R., Raut, S. \& Raut, S. Pilot-scale evaluation of bio-decolorization and biodegradation of reactive textile wastewater: An impact on its use in irrigation of wheat crop. Water Resour. Ind. 21, 100106 (2019). 
45. Shah, M. P. Bioremedial application of bacillus megaterium PMS82 in microbial degradation of acid orange dye. Int. J. Environ. Bioremediation Biodegrad. 2, 93-99 (2014).

46. Chacko, J. T. \& Subramaniam, K. Enzymatic degradation of azo dyes: A review. Int. J. Environ. Sci. 1, 1250-1260 (2011).

47. Mahata, A., Rai, R. K., Choudhuri, I., Singh, S. K. \& Pathak, B. Direct vs. indirect pathway for nitrobenzene reduction reaction on a Ni catalyst surface: a density functional study. Phys. Chem. Chem. Phys. 16, 26365-26374 (2014).

48. Nasrin, T., Saha, A., Mohanta, M. \& Chaity, A\& Rahman, S \& Ruhi, R \& Sarker, S \& Haque, M. ,. Decolourization of azo dye by indigenous bacteria and its impact on seed germination. Int. J. Biosci. 14, 197-210 (2019).

49. Zhou, X. \& Xiang, X. Effect of different plants on azo-dye wastewater bio-decolorization. Procedia Environ. Sci. 18, 540-546 (2013).

50. Li, J., Shao, Z., Chen, C. \& Wang, X. Hierarchical GOs/Fe $3 \mathrm{O} 4$ /PANI magnetic composites as adsorbent for ionic dye pollution treatment. RSC Adv. 4, 38192 (2014).

51. Saini, R. D. Textile organic dyes: Polluting effects and elimination methods from textile waste water. Int. J. Chem. Eng. Res. 9, 121-136 (2017).

52. Caritá, R. \& Marin-Morales, M. A. Induction of chromosome aberrations in the Allium cepa test system caused by the exposure of seeds to industrial effluents contaminated with azo dyes. Chemosphere 72, 722-725 (2008).

53. Wijeyaratne, W. M. D. N. \& Wickramasinghe, P. G. M. U. Chromosomal abnormalities in allium cepa induced by treated textile effluents: Spatial and temporal variations. J. Toxicol. 2020, 1-10 (2020).

54. Jadhav, J. P., Kalyani, D. C., Telke, A. A., Phugare, S. S. \& Govindwar, S. P. Evaluation of the efficacy of a bacterial consortium for the removal of color, reduction of heavy metals, and toxicity from textile dye effluent. Bioresour. Technol. 101, 165-173 (2010).

55. Liang, J. et al. Toxicity evaluation of textile dyeing effluent and its possible relationship with chemical oxygen demand. Ecotoxicol. Environ. Saf. 166, 56-62 (2018).

56. Zheng, Q. et al. Self-organized $\mathrm{TiO} 2$ nanotube array sensor for the determination of chemical oxygen demand. Adv. Mater. 20, 1044-1049 (2008).

57. Gholami-Borujeni, F., Nejatzadeh-Barandozi, F. \& Aghdasi, H. Data on effluent toxicity and physicochemical parameters of municipal wastewater treatment plant using Daphnia Magna. Data Br. 19, 1837-1843 (2018).

\section{Acknowledgements}

This study has been funded by the Department of Science and Technology (DST/SSTP/Odisha/443) and is greatly acknowledged. We are grateful to the Center for Biotechnology, Siksha 'O' Anusandhan (Deemed to be University), Bhubaneswar, for their support and encouragement. We also greatly acknowledge SAIF Chandigarh for their support in LCMS analysis.

\section{Funding}

This study has been funded by the Department of Science and Technology (DST/SSTP/Odisha/443) and is greatly acknowledged.

\section{Declarations}

\section{Competing interests}

Not applicable.

\section{Additional information}

Correspondence and requests for materials should be addressed to S.R.

Reprints and permissions information is available at www.nature.com/reprints.

Publisher's note Springer Nature remains neutral with regard to jurisdictional claims in published maps and institutional affiliations.

(c) (i) Open Access This article is licensed under a Creative Commons Attribution 4.0 International License, which permits use, sharing, adaptation, distribution and reproduction in any medium or format, as long as you give appropriate credit to the original author(s) and the source, provide a link to the Creative Commons licence, and indicate if changes were made. The images or other third party material in this article are included in the article's Creative Commons licence, unless indicated otherwise in a credit line to the material. If material is not included in the article's Creative Commons licence and your intended use is not permitted by statutory regulation or exceeds the permitted use, you will need to obtain permission directly from the copyright holder. To view a copy of this licence, visit http://creativecommons.org/licenses/by/4.0/.

(C) The Author(s) 2021 